\title{
Pengaruh Kompetensi Sosial Guru PAI terhadap Prestasi Belajar Siswa pada Mata Pelajaran Akidah Akhlak Kelas VII di Madrasah Tsanawiyah Negeri Model Makassar
}

\author{
Ulva Muthmainnah Rasyid \\ Hairiyah \\ PAI Universitas Alma Ata \\ email: hairiyahhamid@gmail.com
}

\begin{abstract}
This study aims to determine whether there is an influence between Islamic Education Teachers' social competence and student achievement on the subject of moral aqidah in class VII students in MTsN Model Makassar and to find out how such influences happened.

The population on this study was 117 students of class VII MTsN Model Makassar. This study used three methods of data collection; questionnaire, observation, and documentation. Statistical analysis used in this study is an inferential statistical test technique with regard to SPSS 21 and additional help from Microsoft Excel program. This study useda significant level of 5\%.

The result of statistical test on descriptive statistic with inferential technique on the hypothesis shown that "there is influence of Islamic Education Teachers' social competence to the student achievement in subject of moral Aqidah in Grade VII of MTsN Model Makassar" shows that r count> $r$ table $(0208>0,180)$ at significance level of $5 \%$ which means Ha is accepted and Ho is rejected. Regression equation is $Y=53,616+0,334 X$. From that equation, it can be concluded that from each addition of 1 unit of independent variable (Islamic Education Teachers' social competence) will increase a value of dependent variable (student learning achievement) equal to 0,334. The value of determination coefficient (coefficient that explains the percentage (\%) influence of variable $X$ to variable $Y$ ) amounted to 0.043 which means the effect of variable $X$ to variable $Y$ is equal to of $4.3 \%$ while the rest of the percentage is influenced by other variables. In other words there is a significant influence between Islamic Education Teachers' social competence and the student achievement on the subject of moral Aqidah in Grade VII of MTsN Model Makassar
\end{abstract}

Keyword: Teachers’ Social Competence, Student Achievement

\begin{abstract}
Abstrak
Penelitian ini bertujuan untuk mengetahui adalah pengaruh kompetensi sosial guru PAI terhadap prestasi belajar siswa pada mata pelajaran akidah akhlak kelas VII di MTsN Model Makassar dan bagaimanakah pengaruh tersebut.

Populasi penelitian adalah 117 siswa kelas VII MTsN Model Makassar. Pada penelitian ini menggunakan tiga metode pengumpulan data yaitu angket, observasi, dan dokumentasi. Analisis statistik yang digunakan pada penelitian ini adalah tekhnik uji statistik inferensial dengan menggunakan bantuan SPSS 21 dan menggunakan tambahan bantuan program Microsoft Excel. Dalam penelitian ini menggunakan taraf signifikan 5\%.

Hasil uji statistik deskriptiv statistic menggunakan tekhnik inferensial untuk menguji hipotesis “ada pengaruh kompetensi sosial guru PAI terhadap prestasi belajar siswa pada mata
\end{abstract}


pelajaran akidah akhlak kelas VII di MTsN Model Makassar” ini menunjukkan bahwa r hitung > $r$ tabel $(0.208>0,180)$ pada taraf signifikansi 5\% maka Ha diterima dan Ho ditolak. Persamaan regresinya yaitu $Y=53,616+0,334 X$. Dari persamaan tersebut dapat disimpulkan bahwa dari setiap penambahan 1 unit variabel bebas (kompetensi sosial guru PAI) akan meningkatkan nilai variabel terikat (prestasi belajar siswa) sebesar 0,334. Nilai koefisien determinasi (koefisien yang menjelaskan besarnya persentase (\%) pengaruh variabel $X$ terhadap variabel $Y$ ) sebesar 0,043 artinya pengaruh variabel $X$ terhadap variabel $Y$ sebesar 4,3\% sedangkan sisanya dipengaruhi oleh variabel yang lain. Dengan kata lain ada pengaruh kompetensi sosial guru PAI terhadap prestasi belajar siswa pada mata pelajaran akidah akhlak kelas VII di MTsN Model Makassar sebesar $4,3 \%$.

Kata Kunci: Kompetensi Sosial Guru, Prestasi Belajar Siswa

\section{PENDAHULUAN}

Pendidikan sebagai suatu sistem yang mempunyai banyak komponen yang saling berinteraksi, berkolaborasi, dan berinterdependensi untuk mencapai tujuan pendidikan. Dari pengertian tersebut, jelas bahwa pendidikan yang dimaksud tidak hanya mencakup pendidikan umum saja yang hanya menekankan pada IQ (Intelligence Quotient) siswa, akan tetapi pendidikan juga harus mampu meningkatkan EQ (Emotional Quotient) dan SQ (Spritual Quotient) siswa yaitu melalui pendidikan agama. ${ }^{1}$

Madrasah Tsanawiyah Negeri Model Makassar adalah madrasah percontohan. Predikat ini menuntut agar skill para pengelola dan pendidik lebih diprioritaskan dalam menyelenggarakan pendidikan. Kepala madrasah selaku pelayan pertama telah berpartisipasi aktif dengan menggelar berbagai kegiatan pelatihan pengembangan keterampilan dan bakat kompetensi para gurunya, menganjurkan sertifikasi, mendelegasikan para guru untuk mengikuti MGMP (Musyawarah Guru Mata Pelajaran) dan lain sebagainya, demi menemukan formula pengajaran dan pembinaan yang tetap terjaga mutu dan keunggulannya. ${ }^{2}$

${ }^{1}$ Fiska Ilyasir "Pengaruh Pertemanan Sebaya Terhadap Prestasi Belajar PAI Siswa Kelas XI SMA Negeri 1 Sewon Bantul Tahun Pelajaran 2013/2014" dalam Literalisasi : Jurnal Ilmu Pendidikan, Vol. 6, No. 1 Juni 2015, hal, 78

${ }^{2}$ Tamrin, Guru PAI MTsN Model Makassar, wawancara tanggal 30 Agustus 2016.
Realitas yang terjadi di lapangan, ditemukan bahwa sebahagian besar siswa MTsN Model telah mencapai tingkat perolehan prestasi yang membanggakan, walau sebahagian kecil siswa masih ada saja yang memiliki nilai yang belum memuaskan. Demikian juga dengan tingkat kesantunan perilaku siswa secara global, yang juga telah mencapai predikat sangat baik, meski masih ada saja beberapa siswa yang kadang kurang dalam kesantunan yang diharapkan. ${ }^{3}$ Disinilah dituntut sedapat mungkin guru memberikan pengaruh kepada siswa dengan kompetensi yang dimiliki. Diantara kompetensi tersebut ialah kompetensi sosial dengan melakukan pendekatan terhadap siswa dan keluarga siswa.

Di dalam kegiatan sekolah, hal yang paling pokok adalah kegiatan belajar mengajar. Tercapai atau tidaknya suatu tujuan pembelajaran, tergantung bagaimana proses belajar yang dialami oleh peserta didik. ${ }^{4}$

Guru dituntut bukan hanya sekedar menyampaikan mata pelajaran sebagai kewajiban melainkan memberikan pengaruh terhadap perilaku siswa sehingga memberikan dampak yang positif, nilai yang baik dan perilaku yang baik. Guru sebagai teladan bagi siswa-siswanya harus memiliki sikap dan

\footnotetext{
${ }^{3}$ Dokumentasi absensi penilaian siswa di setiap kelas

${ }^{4}$ Khanif Maksum "Penerapan Metode Scramble Untuk Meningatkan Prestasi Belajar SKI Kelas V MI Al-Iman Sorogenen" dalam Literalisasi: Jurnal Ilmu Pendidikan, Vol. 6, No. 1 Juni 2015, hal, 62
} 
kepribadian utuh yang dapat dijadikan tokoh panutan idola dalam seluruh segi kehidupannya. Karenanya guru harus selalu berusaha memilih dan melakukan perbuatan yang positif agar dapat mengangkat citra baik dan kewibawaannya, terutama di depan siswa-siswanya.

Berdasarkan realitas di atas, peneliti tertarik untuk melakukan penelitian mengenai pengaruh kompetensi sosial guru PAI terhadap prestasi belajar siswa pada mata pelajaran akidah akhlak kelas VII di Madrasah Tsanawiyah Negeri Model Makassar.

Konsep mengenai guru sudah banyak sekali para ahli yang membahasnya, Muhaimin menjelaskan bahwa pengertian guru secara umum adalah orang yang berwenang dan bertanggung jawab terhadap pendidikan murid-murid, baik secara individual ataupun klasikal, baik di sekolah maupun di luar sekolah. Islam memandang secara umum guru adalah mengupayakan perkembangan seluruh potensi/ aspek anak didik, baik aspek cognitive, affective dan psychomotor. ${ }^{5}$

Begitu juga pendapat yang searah dari Zakiyah Drajat dalam bukunya ilmu pendidikan islam menjelaskan bahwa seorang guru secara umum dapat diartikan sebagai pendidik profesional, karena secara implisit ia telah merelakan dirinya menerima dan memiliki sebagian tanggung jawab pendidikan. ${ }^{6}$

Adapun istilah kompetensi lahir dari gabungan kemampuan, pengetahuan, kecakapan, sikap, sifat, pemahaman, apresiasi dan harapan yang mendasari karakteristik seseorang untuk berunjuk kerja dalam menjalankan tugas atau pekerjaan guna mencapai standar kualitas dalam pekerjaan nyata. Dalam hal ini kompetensi adalah seperangkat pengetahuan, keterampilan dan perilaku yang harus dimiliki, dihayati dan dikuasai oleh guru untuk dapat melaksanakan tugas-tugas profesionalnya. UU No. 14 tahun 2005 pasal 8 menyatakan guru wajib memiliki

${ }^{5}$ Muhaimin, Pengembangan Kurikulum Pendidikan Agama Islam (Jakarta, Raja Grafindo Persada: 2005) hlm, 44-49

${ }^{6}$ Zakiah Daradjat, Ilmu Pendidikan Islam (Jakarta, Bumi Angkasa: 1984) hlm, 39 kualifikasi akademik, kompetensi, sertifikat pendidik, sehat jasmani dan rohani, serta memilki kemampuan untuk mewujudkan tujuan pendidikan nasional. ${ }^{7}$

Ada empat kompetensi dasar yang harus dimilki oleh seorang guru, antara lain: Kompetensi Kepribadian, Kompetensi Pedagogik, Kompetensi Profesional, dan Kompetensi Sosial. Ini sesuai dengan UU Peraturan Pemerintah No. 14 tahun 2005, pada Pasal 8 mengatakan tentang kompetensi seorang guru. Kompetensi sosial terdiri dari kata kompetensi dan sosial. Kompetensi adalah suatu kata yang berasal dari bahasa Inggris yaitu competency yang mempunyai arti kecakapan atau kemampuan dan wewenang. Kompetensi dalam kamus besar bahasa Indonesia sering artinya disamakan dengan kata kemampuan, kecakapan, dan keahlian.

Kata sosial berasal dari bahasa latin yaitu 'socius' yang berarti segala sesuatu yang lahir, tumbuh, dan berkembang dalam kehidupan bersama. Sosial pada strukturnya, yaitu suatu tatanan dari hubungan-hubungan sosial dalam masyarakat yang menempatkan pihak-pihak tertentu (individu, keluarga, kelompok, kelas) di dalam posisi-posisi sosial tertentu berdasarkan suatu sistem nilai dan norma yang berlaku pada suatu masyarakat pada waktu tertentu. ${ }^{8}$ Menurut salim A kompetensi sosial guru adalah mampu berkomunikasi dan bergaul dengan peserta didik, sesama pendidik dan tenaga kependidikan, orang tua dan wali murid, masayarakat dan lingkungan sekitar, dan mampu mengembangkan jaringan. ${ }^{9}$

Kompetensi sosial dalam kegiatan pembinaan di sekolah menuntut para guru untuk cakap dalam memerankan spesifikasi interaksi yang mempunyai karagter khusus. Kedekatan dengan masyarakat harus terjalin, baik itu yang berada di lingkungan sekolah atau

${ }^{7}$ Syaiful Sagala. Kemampuan Profesional Guru dan Tenaga Kependidikan (Bandung, Alfabeta: 2013) hlm, 23

${ }^{8}$ Salim, A. Perubahan Sosial (Yogyakarta, Tiara Wacana: 2002) hlm, 10

${ }^{9}$ Ibid., hlm, 39 
yang jauh dari lingkungan sekolah yang telah siap memberikan kepercayaan kepada pihak sekolah untuk melakukan pembinaan.

Adapun istilah kompetensi belajar peneliti ambil Dalam Kamus Besar Bahasa Indonesia, prestasi belajar adalah penguasaan pengetahuan atau keterampilan yang dikembangkan oleh mata pelajaran, lazimnya ditunjukkan dengan nilai tes atau angka nilai yang diberikan oleh guru. ${ }^{10}$

Dalam penelitian ini, olahan data prestasi siswa akan diambil dari hasil nilai ujian akidah akhlak semester I tahun pelajaran 2016/2017 di MTsN Model Makassar.

Berdasarkan latar belakang dan kajian teori yang telah dikemukakan diatas, digambarkan dalam bentuk kerangka teori sesuai dengan indikator kompetensi sosial guru PAI sebagai variabel X serta prestasi belajar siswa pada mata pelajaran akidah akhlak sebagai variabel Y.

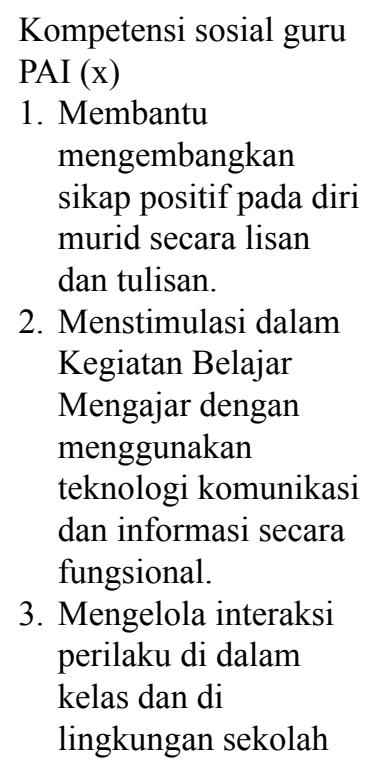

2. Menstimulasi dalam Kegiatan Belajar Mengajar dengan menggunakan teknologi komunikasi dan informasi secara fungsional.

3. Mengelola interaksi perilaku di dalam kelas dan di lingkungan sekolah

Adapun hipotesis dalam penelitian ini akan dapat dirumuskan menjadi hipotesis alternatif(H1) dan hipotesis nihil (H0) sebagai berikut:

H1 : Ada pengaruh kompetensi sosial guru PAI terhadap pretsai belajar siswa pada mata pelajaran akidah akhlak kelas VII di MTsN Model Makassar.

${ }^{10}$ DEPDIKNAS, Kamus Besar Bahasa Indonesia..., hlm. 895
H0 : Tidak ada pengaruh kompetensi sosial guru PAI terhadap prestasi belajar siswa pada mata pelajaran akidah akhlak kelas VII di MTsN Model Makassar.

\section{METODE PENELITIAN}

Penelitian ini menggunakan metode penelitian Kuantitatif. Penelitian kuantitatif adalah penelitian yang berdasarkan pada filsafat positivisme, digunakan untuk meneliti populasi atau sampel tertentu, tekhnik pengambilan sampel pada umumnya dilakukan secara random, pengumpulan data menggunakan instrument penelitian, analisis data bersifat kuantitatif/statistic dengan tujuan untuk menguji hipotesis yang telah ditetapkan. ${ }^{11}$

Penelitian yang digunakan adalah penelitian regresi. Penelitian regresi mengacu pada studi yang bertujuan mengungkapkan pengaruh antar variabel melalui penggunaan statistik regresi linear. ${ }^{12}$ Suharsimi Arikunto juga mengemukakan penelitian regresi adalah penelitian yang dilakukan oleh peneliti untuk mengetahui pengaruh antara dua variabel atau lebih tanpa melakukan perubahan, tambahan atau manipulasi terhadap data yang memang sudah ada. ${ }^{13}$

\begin{tabular}{|c|c|c|}
\hline $\begin{array}{c}\text { Kompetensi } \\
\text { sosial guru } \\
\text { PAI } \\
\text { (Variabel X) }\end{array}$ & $\mathrm{Y}=\mathrm{a}+\mathrm{bX}$ & $\begin{array}{c}\text { Prestasi siswa } \\
\text { pelajaran } \\
\text { akidah akhlak } \\
\text { (Variabel } \mathrm{Y})\end{array}$ \\
\hline
\end{tabular}

Adapun subyek penelitian dalam penelitian ini adalah siswa kelas VII-1 (19 orang), kelas VII-2 (20 orang), kelas VII-3 (20 oang), kelas VII-4 (20 orang), kelas VII-5 (19 orang), kelas VII-6 (19 orang) di MTsN Model Makassar. ${ }^{14}$

${ }^{11}$ Sugiono, Metode PenelitianPendidikan, Pendekatan Kuantitatif, Kualitatif, dan R\&D (Bandung, Alfabeta: 2012) hlm, 15

${ }^{12}$ Sulaiman, Analisa regresi menggunakan SPSS (Yogyakarta, Gadjah Mada University Press: 2004) hlm, 15

${ }^{13}$ Suharsimi Arikunto, Prosedur Penelitian: Suatu Pendekatan Praktek (Jakarta, PT. Rineka Cipta: 2002) hlm, 112

${ }^{14}$ Dokumentasi data siswa MTsN Model Makassar

LITERASI, Volume VIII, No. 2 2017 | 141 
Dari semua kelas tersebut berjumlah 117 siswa kelas VII MTsN Model Makassar.

Dalam penelitian ini menggunakan populasi karena jumlah siswa kelas VII yang diteliti tidak jauh dari angka 100. Populasi yang peneliti gunakan berjumlah 117 siswa yang ada di kelas VII MTsN Model Makassar.

Adapun variabel dalam penelitian ini terdapat dua variabel, satu variabel bebas dan satu variabel terikat yaitu: Variabel bebas (X) dalam penelitian ini adalah kompetensi sosial guru PAI yang terdapat di MTsN Model Makassar, sedangkan variabel terikat (Y) dalam penelitian ini prestasi belajar siswa pada mata pelajaran akidah akhlak kelas VII di MTsN Model Makassar

Adapun metode pengumpulan data yang digunakan penulis dalam penelitian ini meliputi : Kuesioner, Observasi dan Dokumentasi

Untuk Instrumen penelitian dalam keabsahannya dilakukan dengan cara pengujian validitas dan reliabilitas..$^{15}$

Dalam pengujian validitas data dikatakan valid apabila data tersebut terdapat kesamaan antara data yang terkumpul dengan data yang sesungguhnya terjadi pada obyek yang diteliti. ${ }^{16}$ Uji validitas menggunakan rumus Product Moment dengan taraf signifikan 5\%=

Sedangkan pengujian Reliabilitas menunjukkan bahwa suatu instrumen cukup dapat dipercaya untuk digunakan sebagai alat pengumpulan data karena instrumen tersebut sudah baik. ${ }^{17}$ Dalam penelitian ini digunakan rumus Cronbach'a Alpha untuk menguji reliabilitas instrumen dengan taraf signifikan $5 \%$, sebab jenis datanya yaitu data interval yang diperoleh melalui angket.

Adapun Pengolahan data dalam penelitian ini melalui: editing, coding (pengkodean), dan pemberian skor atau nilai. Sedangkan Metode analisis yang digunakan dalam penelitian ini adalah Analisis Deskriptif Persentase. Metode ini digunakan untuk mengkaji variabel yang ada hlm. 173

${ }^{15}$ Sugiyono, Metode Penelitian Pendidikan...,

${ }^{16}$ Sugiyono, Statistik Untuk Pendidikan (Bandung, Alfabeta: 2010) hlm, 348

${ }^{17}$ Ibid..,hlm. 154 pada penelitian yaitu kompetensi sosial guru PAI (X) dan prestasi belajar siswa pada mata pelajaran akidah akhlak kelas VII(Y). Deskriptif persentase ini diolah dengan cara frekuensi dibagi dengan jumlah responden dikali 100 persen.

Penghitungan deskriptif persentase ini mempunyai langkah-langkah sebagai berikut: Mengkoreksi jawaban kuesioner dari responden, menghitung frekuensi jawaban responden, jumlah responden keseluruhan adalah 117 orang, dan Masukkan ke dalam rumus

\section{PEMBAHASAN}

\section{Kompetensi Sosial Guru PAI di MTsN Model Makassar}

Berdasarkan hasil angket yang diberikan kepada 117 responden di MTsN Model Makassar untuk mengetahui kompetensi sosial guru PAI di MTsN Model Makassar maka diperoleh data penelitian, analisis data hasil penelitiannya akan disajikan dalam bentuk tabel distribusi frekuensi dengan menggunakan Win. SPSS 21.

Tabel 1. Analisis data rentang skor kompetensi sosial guru PAI

\begin{tabular}{cccc}
\hline Rentang & \multicolumn{2}{c}{ Kompetensi Sosial Guru } & \multirow{2}{*}{ Keterangan } \\
\cline { 2 - 3 } Skor & $\mathrm{F}$ & $\%$ & \\
\hline $86-100$ & 102 & 87.18 & Sangat baik \\
$1-85$ & 15 & 12.82 & Baik \\
$56-70$ & 0 & 0 & Cukup baik \\
$41-55$ & 0 & 0 & Kurang \\
$<<40$ & 0 & 0 & Sangat kurang \\
\hline TTotal & 117 & 100 & \\
\hline
\end{tabular}

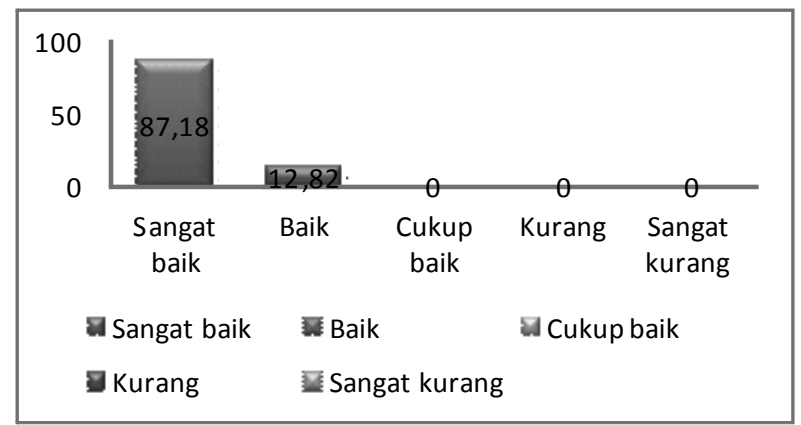

Grafik 1. Rentang skor kompetensi sosial guru PAI

Dari data yang telah dikemukakan di atas tentang kompetensi sosial guru PAI di MTsN 
Model Makassar melalui hasil angket yang menyatakan sebagian besar siswa berpendapat bahwa guru PAI berada pada kualifikasi nilai rata-rata sangat baik dengan rentang nilai 86100 dengan jumlah 102 orang peserta didik $(87,18 \%)$ yang memberikan penilaian, pada kategori baik dengan rentang nilai 71-85 dengan jumlah 15 orang peserta didik $(12,82 \%)$ yang memberikan penilaian. Jadi dapat disimpulkan bahwa kompetensi sosial guru kelas VII sudah sangat baik.

\section{Prestasi Belajar Siswa di MTsN Model Makassar}

Berdasarkan hasil data prestasi belajar siswa MTsN Model Makassar yang telah dikemukakan di atas maka diperoleh data penelitian, analisis data hasil penelitiannya akan disajikan dalam bentuk tabel distribusi frekuensi dengan menggunakan Win. SPSS 21 sebagai berikut:

Tabel 2. Analisis data rentang skor prestasi belajar siswa

\begin{tabular}{|c|c|c|c|}
\hline \multirow{2}{*}{$\begin{array}{c}\text { Rentang } \\
\text { skor }\end{array}$} & \multicolumn{2}{|c|}{ Prestasi Belajar Siswa } & \multirow[t]{2}{*}{ Keterangan } \\
\hline & $\mathrm{F}$ & $\%$ & \\
\hline $86-100$ & 70 & 59.83 & Sangat baik \\
\hline $71-85$ & 47 & 40.17 & Baik \\
\hline $56-70$ & 0 & 0 & Cukup baik \\
\hline $41-55$ & 0 & 0 & Kurang \\
\hline$<40$ & 0 & 0 & Sangat kurang \\
\hline Total & 117 & 100 & \\
\hline
\end{tabular}

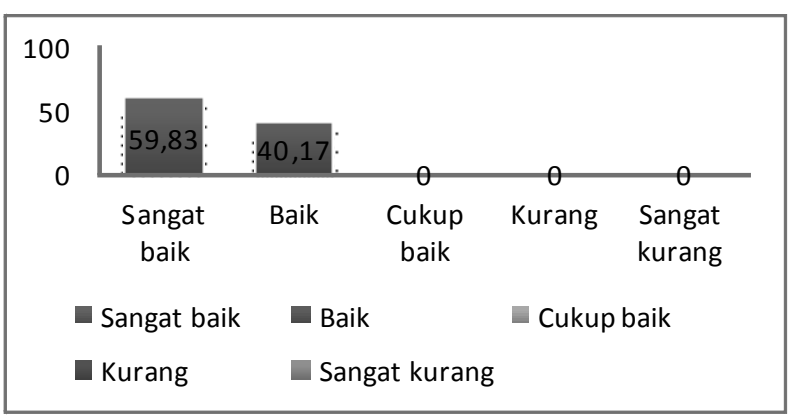

Grafik 2. Rentang skor prestasi belajar siswa

Dari data yang telah dikemukakan di atas maka dapat disimpulkan bahwa prestasi belajar siswa pada mata pelajaran akidah akhlak kelas VII di MTsN Model Makassar berada pada kualifikasi nilai kategori sangat baik dengan rentang nilai 86-100 dengan jumlah 70 $(59,83 \%)$ orang peserta didik, sedangkan pada kategori baik dengan rentang nilai 71-85 dengan jumlah 47 (40,17\%) orang peserta didik.

\section{Pengaruh kompetensi sosial guru PAI terhadap prestasi belajar siswa pada mata pelajaran akidah akhlak kelas VII di MTsN Model Makassar}

Hasil perhitungan data pengaruh kompetensi sosial guru terhadap prestasi belajar siswa diolah dengan bantuan SPSS Ver. 21 maka didapat hasil statistik dasar seperti pada tabel sebagai berikut:

Tabel 3. Deskripsi pengaruh kompetensi sosial guru terhadap prestasi belajar siswa

\begin{tabular}{cccc}
\hline No & Deskriptif & $\begin{array}{c}\text { Kompetensi } \\
\text { Sosial Guru }\end{array}$ & $\begin{array}{c}\text { Prestasi } \\
\text { Peserta Didik }\end{array}$ \\
\hline 1. & $\mathrm{~N}$ & 117 & 117 \\
2. & Mean & 89 & 87 \\
3. & Std Deviation & 2.83 & 6.44 \\
4. & Minimum & 82 & 76 \\
5. & Maximum & 93 & 100 \\
\hline
\end{tabular}

Pada tabel terlihat bahwa dalam statistik deskriptif pada kompetensi sosial guru dan prestasi belajar peserta didik terdapat perbedaan rata-rata diantara keduanya tersebut, dimana nilai rata-rata kompetensi sosial guru lebih tinggi dibanding dengan prestasi belajar peserta didik dengan selisih 2 (89-87), pada tingkat nilai standar deviasi nilai prestasi belajar peserta didik lebih tinggi dengan selisih 3,60 (6,442,83 ), pada tingkat minimum nilai kompetensi sosial guru lebih tinggi dibanding dengan prestasi belajar peserta didik dengan selisih 6 (82-76), dan pada tingkat maximum nilai prestasi belajar peserta didik lebih tinggi dengan selisih 7 (100-93).

Untuk mengetahui ada tidaknya pengaruh kompetensi sosial guru PAI terhadap prestasi belajar siswa pada mata pelajaran akidah akhlak kelas VII di MTsN Model Makassar langkah-langkah kerja yang dilakukan adalah merumuskan Hipotesis 
$\mathrm{Ha}$ : "Ada pengaruh kompetensi sosial guru PAI terhadap prestasi belajar siswa pada mata pelajaran akidah akhlak kelas VII di MTsN Model Makassar."

H0 : "Tidak ada pengaruh kompetensi sosial guru PAI terhadap prestasi belajar siswa pada mata pelajaran akidah akhlak kelas VII di MTsN Model Makassar.”

Langkah selanjutnya adalah menganalisis data. Dalam penelitian ini menggunakan bantuan komputer program SPSS for windows versi 21.0. Hasil perhitungan sebagai berikut:

Tabel 4. Deskriptif Statistik

\begin{tabular}{lccc}
\hline & Mean & $\begin{array}{c}\text { Std. } \\
\text { Deviation }\end{array}$ & $\mathrm{N}$ \\
\hline Kompetensi Sosial Guru & 89.1709 & 2.83236 & 117 \\
\hline $\begin{array}{l}\text { Prestasi Belajar Peserta } \\
\text { Didik }\end{array}$ & 86.8462 & 6.43618 & 117 \\
\hline
\end{tabular}

Tabel deskriptif statistik di atas dapat diketahui Variabel kompetensi sosial guru besarnya mean 89.1709 standar deviasinya 2.83236 dan N 177. Variabel prestasi belajar peserta didik, mean 86.8462 standar deviasinya 6.43618 dan N 117.

Tabel 5. Hasil Analisis Data

\section{Correlations}

\begin{tabular}{|c|c|c|c|}
\hline & & Kompetensi & Prestasi \\
\hline \multirow{4}{*}{$\begin{array}{l}\text { Kompetensi } \\
\text { Sosial Guru }\end{array}$} & Pearson & & \\
\hline & Correlation & 1 & .208 \\
\hline & Sig. (2-tailed) & & .000 \\
\hline & $\mathrm{N}$ & 117 & 117 \\
\hline \multirow{4}{*}{$\begin{array}{l}\text { Prestasi } \\
\text { Belajar } \\
\text { Peserta } \\
\text { Didik }\end{array}$} & Pearson & \multirow{2}{*}{.208} & \multirow{2}{*}{1} \\
\hline & Correlation & & \\
\hline & Sig. (2-tailed) & .000 & \\
\hline & $\mathrm{N}$ & 117 & 117 \\
\hline
\end{tabular}

Tabel di atas menunjukkan bahwa nilai korelasi pengaruh kompetensi sosial guru terhadap prestasi belajar peserta didik adalah sebesar 0,208.

Kriteria kuat lemahnya hubungan antara 2 variabel dapat dilihat pada tabel berikut ini :
Tabel 6. Pedoman Untuk Memberikan Interpretasi Koefisien Korelasi ${ }^{18}$

\begin{tabular}{cc}
\hline Interval Korelasi & Tingkat Hubungan \\
\hline $0,00-0,199$ & Sangat Rendah \\
$0,20-0,399$ & Rendah \\
$0,40-0,599$ & Cukup \\
$0,60-0,799$ & Kuat \\
$0,80-1,00$ & Sangat Kuat \\
\hline
\end{tabular}

Angka "r" hitung kompetensi sosial guru PAI dengan prestasi belajar siswa pada mata pelajaran akidah akhlak kelas VII di MTsN Model Makassar adalah 0,208, sehingga apabila "r" hitung terdapat di kisaran 0,20 - 0,399 maka tingkat hubungan kompetensi sosial guru PAI terhadap prestasi belajar siswa pada mata pelajaran akidah akhlak kelas VII di MTsN Model Makassar masih rendah.

Apabila dikonsultasikan pada nilai " $r$ " product moment, dengan $\mathrm{N}$ sebesar 177 dengan taraf signifikansi 5\% yaitu memiliki nilai 0,180. Sehingga $r$ hitung $>r$ tabel yakni $0.208>0,180$. Dengan demikian, berdasarkan hasil perhitungan diketahui bahwa terdapat korelasi yang positif antara kompetensi sosial guru $(\mathrm{X})$ dengan prestasi belajar siswa (Y) pada mata pelajaran akidah akhlak kelas VII di MTsN Model Makassar.

Tabel 7. Hasil analisis regresi anova

\begin{tabular}{cccccc}
\hline Model & $\begin{array}{c}\text { Sum of } \\
\text { Squares }\end{array}$ & df & $\begin{array}{c}\text { Mean } \\
\text { Square }\end{array}$ & F & Sig. \\
\hline Regression & 189,236 & 1 & 189,236 & 5,217 &, $024^{\mathrm{b}}$ \\
Residual & 4171,089 & 115 & 36,270 & & \\
& & & & & \\
Total & 4360,325 & 116 & & & \\
\hline a. Dependent Variable: Y & & & \\
Sumber : Olah Data SPSS 21.0 \\
b. Predictors: (Constant), X
\end{tabular}

Selanjutnya untuk mengetahui pengaruh kompetensi sosial terhadap prestasi belajar peserta didik dilakukan analisis regresi sederhana. Hasil perhitungan dengan menggunakan alat bantu SPSS vers. 21 diperoleh hasil penghitungan koefisien regresi dan nilai konstanta seperti pada tabel berikut: hlm. 257
${ }^{18}$ Sugiyono, Metode Penelitian Pendidikan....., h.m. 257 
Tabel 8. Hasil analisis regresi

Model Summary

\begin{tabular}{|c|c|c|c|c|}
\hline Model & $\mathrm{R}$ & $\begin{array}{c}\mathrm{R} \\
\text { Square }\end{array}$ & $\begin{array}{c}\text { Adjusted R } \\
\text { Square } \\
\end{array}$ & $\begin{array}{c}\text { Std. Error of the } \\
\text { Estimate }\end{array}$ \\
\hline 1 &, $208^{a}$ & ,043 &, 035 & 6,02249 \\
\hline
\end{tabular}

Tabel di atas menjelaskan tentang besarnya nilai korelasi yang dilambangkan dengan $(\mathrm{R})$, yaitu sebesar 0,208 . Sedangkan pada kolom $R$ Square yang menjelaskan besarnya persentase (\%) pengaruh variabel $X$ terhadap variabel $Y$ yang disebut dengan koefisien determinasi. Dari Tabel diperoleh nilai koefisien determinasi sebesar 0,043 artinya pengaruh variabel $\mathrm{X}$ terhadap variabel $\mathrm{Y}$ sebesar 4,3\% sedangkan sisanya dipengaruhi oleh variabel yang lain. Hal ini juga menjelaskan bahwa variabel $\mathrm{X}$ memberikan kontribusi sebesar 4,3\% terhadap variabel $\mathrm{Y}$.

Tabel di atas menjelaskan apakah ada pengaruh yang nyata (signifikan) variabel $\mathrm{X}$ terhadap variabel Y. Dari output tersebut terlihat bahwa $\mathrm{F}$ hitung $=5,217$ dengan tingkat signifikansi/Probabilitas 0,024 $<0,05$, maka maka $\mathrm{H}_{0}$ ditolak dan $\mathrm{H}_{1}$ diterima.

Tabel 9. Hasil analisi regresi coefficients Coefficients $^{\mathbf{a}}$

\begin{tabular}{|c|c|c|c|c|c|c|}
\hline \multirow{2}{*}{\multicolumn{2}{|c|}{ Model }} & \multicolumn{2}{|c|}{$\begin{array}{c}\text { Unstandardized } \\
\text { Coefficients }\end{array}$} & \multirow{2}{*}{$\begin{array}{c}\text { Standardized } \\
\text { Coefficients }\end{array}$} & \multirow[t]{2}{*}{$\mathrm{t}$} & \multirow[t]{2}{*}{ Sig. } \\
\hline & & B & $\begin{array}{l}\text { Std. } \\
\text { Error }\end{array}$ & & & \\
\hline \multirow{2}{*}{1} & (Constant) & 53,616 & 14,574 & & 3,679 & , 000 \\
\hline & $X$ & ,334 &, 146 & 208 & 2,284 &, 024 \\
\hline
\end{tabular}

a. Dependent Variable: Y

Sumber : Olah Data SPSS 21.0

Tabel di atas menjelaskan pada kolom B nilai constant (a) adalah 53,616 sedangkan nilai variabel X (b) adalah 0,334 sehingga persamaan regresi yang menjelaskan pengaruh kompetensi sosial PAI terhadap prestasi hasil belajar siswa adalah: $\mathrm{Y}=53,616+0,334 \mathrm{X}$

Dari persamaan di atas dapat disimpulkan bahwa dari setiap penambahan 1 unit variabel bebas (kompetensi sosial guru PAI) akan meningkatkan nilai variabel terikat (prestasi belajar siswa) sebesar 0,334 .
Sedangkan untuk nilai t hitung $=2,284$ dengan nilai signifikansi $0,024<0,05$ Sehingga dapat disimpulkan bahwa $\mathrm{HO}$ ditolak dan berarti terdapat pengaruh yang signifikan dari variabel bebas (kompetensi sosial guru PAI) terhadap variabel terikat (prestasi belajar siswa).

\section{KESIMPULAN}

Dari hasil penelitian yang berjudul "Pengaruh kompetensi sosial guru PAI terhadap prestasi belajar siswa pada pelajaran akidah akhlak kelas VII di MTsN Model Makassar" dengan mengacu pada data yang telah terkumpul dan telah dianalisis, maka peneliti merangkum kesimpulan sebagai berikut :

Kompetensi sosial guru PAI di MTsN Model Makassar dapat dilihat dari hasil angket yang menyatakan sebagian besar siswa berpendapat bahwa guru PAI berada pada kualifikasi nilai rata-rata sangat baik dengan rentang nilai 86-100 dengan jumlah 102 $(87,18 \%)$ orang peserta didik yang memberikan penilaian, sedangkan pada kategori baik dengan rentang nilai 71-85 dengan jumlah 15 (12,82\%) orang peserta didik yang memberikan penilaian. Jadi dapat disimpulkan bahwa kompetensi sosial guru kelas VII sudah sangat baik.

Prestasi belajar siswa pada mata pelajaran akidah akhlak kelas VII di MTsN Model Makassar berada pada kualifikasi nilai kategori sangat baik dengan rentang nilai 86-100 dengan jumlah $70(59,83 \%)$ orang peserta didik, sedangkan pada kategori baik dengan rentang nilai 71-85 dengan jumlah 47 (40,17\%) orang peserta didik.

Angka " $r$ " hitung kompetensi sosial guru dengan prestasi belajar siswa pada mata pelajaran akidah akhlak kelas VII di MTsN Model Makassar adalah 0,208, sehingga apabila " $r$ " hitung terdapat di kisaran 0,20 - 0,399 maka tingkat hubungan kompetensi sosial guru PAI terhadap prestasi belajar siswa pada mata pelajaran akidah akhlak kelas VII di MTsN Model Makassar masih rendah. Apabila dikonsultasikan pada nilai " $r$ " product moment, dengan $\mathrm{N}$ sebesar 177 dengan taraf signifikansi $5 \%$ yaitu memiliki nilai 0,180 . Sehingga $r$ hitung 
$>$ r tabel yakni 0,208>0,180. Dengan demikian, berdasarkan hasil perhitungan diketahui bahwa terdapat korelasi yang positif antara kompetensi sosial guru (X) dengan prestasi belajar siswa (Y) pada mata pelajaran akidah akhlak kelas VII di MTsN Model Makassar.

Adapun pengaruh kompetensi sosial guru PAI terhadap prestasi belajar siswa pada mata pelajaran akidah akhlak kelas VII di MTsN Model Makassar dilakukan analisis regresi sederhana, yaitu : (1) Hasil analisis regresi model summary menjelaskan bahwa besarnya nilai korelasi yang dilambangkan dengan $(\mathrm{R})$, yaitu sebesar 0,208. Sedangkan nilai koefisien determinasi (koefisien yang menjelaskan besarnya persentase $(\%)$ pengaruh variabel $\mathrm{X}$ terhadap variabel $\mathrm{Y}$ ) sebesar 0,043 artinya pengaruh variabel $\mathrm{X}$ terhadap variabel $\mathrm{Y}$ sebesar $4,3 \%$ sedangkan sisanya dipengaruhi oleh variabel yang lain. (2) Hasil analisis regresi anova menjelaskan bahwa nilai $\mathrm{F}$ hitung $=5,217$ dengan tingkat signifikansi/ Probabilitas $0,024<0,05$, maka maka $\mathrm{H}_{0}$ ditolak dan $\mathrm{H}_{1}$ diterima. (3) Hasil analisis regresi coefficients menjelaskan bahwa nilai constant (a) adalah 53,616 sedangkan nilai variabel X (b) adalah 0,334 sehingga persamaan regresi yang menjelaskan pengaruh kompetensi sosial PAI terhadap prestasi hasil belajar siswa adalah $\mathrm{Y}=53,616+0,334 \mathrm{X}$. Dari persamaan di atas dapat disimpulkan bahwa dari setiap penambahan 1 unit variabel bebas (kompetensi sosial guru PAI) akan meningkatkan nilai variabel terikat (prestasi belajar siswa) sebesar 0,334 . Sedangkan untuk nilai t hitung $=2,284$ dengan nilai signifikansi $0,024<0,05$ Sehingga dapat disimpulkan bahwa $\mathrm{H} 0$ ditolak dan berarti terdapat pengaruh yang signifikan dari variabel bebas (kompetensi sosial guru PAI) terhadap variabel terikat (prestasi belajar siswa).

\section{DAFTAR PUSTAKA}

Fiska Ilyasir "Pengaruh Pertemanan Sebaya Terhadap Prestasi Belajar PAI Siswa Kelas XI SMA Negeri 1 Sewon Bantul Tahun Pelajaran 2013/2014" dalam Literalisasi : Jurnal Ilmu Pendidikan, Vol. 6, No. 1 Juni 2015.

Khanif Maksum "Penerapan Metode Scramble Untuk Meningatkan Prestasi Belajar SKI Kelas V MI Al-Iman Sorogenen" dalam Literalisasi : Jurnal Ilmu Pendidikan, Vol. 6, No. 1 Juni 2015.

Muhaimin. 2015. Pengembangan Kurikulum Pendidikan Agama Islam. Jakarta: Raja Grafindo Persada.

Salim, A. 2002. Perubahan Sosial. Yogyakarta: Tiara Wacana.

Sugiono. 2012. Metode Penelitian Pendidikan, Pendekatan Kuantitatif, Kualitatif, dan $R \& D$. Bandung, Alfabeta.

Sugiyono. 2010. Statistik Untuk Pendidikan. Bandung, Alfabeta.

Suharsimi Arikunto. 2002. Prosedur Penelitian: Suatu Pendekatan Praktek. Jakarta, PT. Rineka Cipta.

Sulaiman. 2004. Analisa regresi menggunakan SPSS. Yogyakarta: Gadjah Mada University Press.

Syaiful Sagala. 2013. Kemampuan Profesional Guru dan Tenaga Kependidikan. Bandung: Alfabeta.

Zakiah Daradjat. 1984. Ilmu Pendidikan Islam. Jakarta: Bumi Angkasa. 